\title{
Autosomal recessive limb-girdle muscular dystrophies in the Czech Republic
}

\author{
Kristýna Stehlíková1,2, Daniela Skálová1,2, Jana Zídková ${ }^{1,2}$, Lenka Mrázová3, Petr Vondráček ${ }^{3}$, Radim Mazanec ${ }^{4}$, \\ Stanislav Voháňka ${ }^{5}$, Jana Haberlová ${ }^{6}$, Markéta Hermanováa, Josef Zámečník ${ }^{8}$, Ondřej Souček ${ }^{9}$, Hana Ošlejšková3 \\ Nina Dvořáčková ${ }^{10}$, Pavla Solařová ${ }^{11}$ and Lenka Fajkusová ${ }^{1,2^{*}}$
}

\begin{abstract}
Background: Autosomal recessive limb-girdle muscular dystrophies (LGMD2) include a number of disorders with heterogeneous etiology that cause predominantly weakness and wasting of the shoulder and pelvic girdle muscles. In this study, we determined the frequency of LGMD subtypes within a cohort of Czech LGMD2 patients using mutational analysis of the CAPN3, FKRP, SGCA, and ANO5 genes.

Methods: PCR-sequencing analysis; sequence capture and targeted resequencing.

Results: Mutations of the CAPN3 gene are the most common cause of LGMD2, and mutations in this gene were identified in 71 patients in a set of 218 Czech probands with a suspicion of LGMD2. Totally, we detected 37 different mutations of which 12 have been described only in Czech LGMD2A patients. The mutation c.550delA is the most frequent among our LGMD2A probands and was detected in $47.1 \%$ of CAPN3 mutant alleles. The frequency of particular forms of LGMD2 was 32.6\% for LGMD2A (71 probands), 4.1\% for LGMD2I (9 probands), 2.8\% for LGMD2D (6 probands), and 1.4\% for LGMD2L (3 probands).

Further, we present the first results of a new approach established in the Czech Republic for diagnosis of neuromuscular diseases: sequence capture and targeted resequencing. Using this approach, we identified patients with mutations in the DYSF and SGCB genes.

Conclusions: We characterised a cohort of Czech LGMD2 patients on the basis of mutation analysis of genes associated with the most common forms of LGMD2 in the European population and subsequently compared the occurrence of particular forms of LGMD2 among countries on the basis of our results and published studies.
\end{abstract}

Keywords: Calpain-3, CAPN3, Limb girdle muscular dystrophy, LGMD2, Sequence capture

\section{Background}

Limb-girdle muscular dystrophies (LGMD) are characterised by wide clinical and genetic heterogeneity. Considering this factor, achieving a precise diagnosis can be difficult and requires a comprehensive clinical and laboratory approach. LGMD are classified on the basis of an inheritance pattern and a genetic cause. Limb-girdle muscular dystrophies of type 1 (LGMD1) include forms of the disorder that have an autosomal dominant inheritance associated with a mutation in one of at least 8

\footnotetext{
*Correspondence: lenka.fajkus@gmail.com

'Centre of Molecular Biology and Gene Therapy, University Hospital Brno, Černopolní 9, 61300 Brno, Czech Republic

${ }^{2}$ Central European Institute of Technology, Masaryk University, Kamenice 5, CZ-62500 Brno, Czech Republic

Full list of author information is available at the end of the article
}

genes (LGMD1A-1H). Limb-girdle muscular dystrophies of type 2 (LGMD2) include forms with an autosomal recessive inheritance and mutations in one of at least 16 genes (LGMD2A-Q).

It is helpful to take into account the geographical and ethnic origins of patients in differential diagnosis, since the relative local frequency of the different forms of LGMD varies considerably [1-4]. The clinical course of LGMD ranges from severe to milder forms with different age of onset and progression even within the same family [5]. Diagnosis of LGMD relies on a combination of clinical findings, results of histopathological examination of muscle biopsies (including the analysis of muscle proteins using immunohistochemistry and/or immunoblotting), followed by DNA sequencing to identify the primary mutation, 
which is essential for the provision of genetic and prognostic counselling.

The most frequent form of LGMD2 in Europe is probably LGMD2A, caused by mutations in the calpain-3 gene (CAPN3). This gene encodes a muscle-specific member of the family of $\mathrm{Ca}^{2+}$-activated neutral proteases that is important for muscle remodelling [6-8]. A marked clinical heterogeneity is observed in calpainopathies. While null-type gene mutations are usually associated with absence of calpain-3 protein in muscle and a severe phenotype, missense-type mutations are associated with unpredictable effects at both the protein and the phenotype levels [9-11].

Mutations in the fukutin-related protein gene (FKRP) result in two distinct allelic diseases: severe congenital muscular dystrophy and LGMD2I [12]. This gene encodes a putative Golgi-resident glycosyltransferase that is involved in posttranslational glycosylation of $\alpha$-dystroglycan. The missense mutation c.826C > A, p.Leu276lle is particularly common in LGMD2I patients and has been reported to confer a relatively mild phenotype when present in the homozygous state [13-15].

LGMD2C-2F is due to mutations in the genes encoding the components of the sarcoglycan (SG) complex. This complex, composed of 5 glycoproteins $\left(\alpha-, \beta-, \gamma^{-}, \delta_{-}^{-}\right.$, $\varepsilon-\mathrm{SG}$ ), is a member of the dystrophin-associated glycoprotein (DAG) complex localised to the sarcolemma of muscle fibres, which acts as a link between the extracellular matrix and the cytoskeleton, confers structural stability, and protects the sarcolemma from mechanical stress developed during muscle contraction. The clinical phenotype of sarcoglycanopathies ranges from a severe Duchenne-like dystrophy to a relatively mild LGMD [16]. Although the relative frequency of mutations in the different sarcoglycan genes varies from population to population, $\alpha$-sarcoglycanopathy (LGMD2D) appears to be the most frequent [17].

Recently, recessive mutations in the anoctamin 5 gene (ANO5) were identified as a cause of LGMD2L and nondysferlin Miyoshi myopathy [18,19]. ANO5 encodes a member of the anoctamin family of proteins which contains eight transmembrane domains. Dominant mutations in the ANO5 gene are associated with the skeletal disorder gnathodiaphyseal dysplasia [20]. While the role of ANO5 is unknown, ANO1 and ANO2, which share significant sequence homology with ANO5, are known to be calciumactivated chloride channels [21-23]. In one study [24], analysis of ANO5 was performed in a group of 59 British and German probands, and the mutation c.191dupA was found in 15 patients, homozygously in 11 and in compound heterozygosity with another ANO5 variant in the rest. An intragenic SNP and an extragenic microsatellite marker were in linkage disequilibrium with the mutation, suggesting a founder effect in the populations analysed.
In this study, we determined the frequency of LGMD subtypes within a cohort of Czech LGMD2 patients using mutation analysis of the CAPN3, FKRP, SGCA, and $A N O 5$ genes. We also describe two patients with mutations in the gene encoding dysferlin (DYSF) and a patient with mutations in the gene encoding $\beta$-sarcoglycan $(S G C B)$. These mutations were identified using Sequence capture and targeted resequencing (SeqCap-TR), a method for the capture and enrichment of selected genomic regions from full genomic DNA in a single step which, in association with targeted resequencing, allows one to focus on genomic regions of interest to discover causative mutations.

\section{Methods}

\section{Patients}

For analysis of genes associated with LGMD2, patients' blood or DNA were sent to the Centre of Molecular Biology and Gene Therapy, University Hospital Brno (as the only laboratory performing LGMD genetic testing in the Czech Republic) from the Departments of Neurology and Medical Genetics of University Hospitals located in Brno, Prague, Ostrava, and Hradec Králové. Patients were included into the study on the basis of fulfilment of the following criteria: 1) a clinical phenotype characterized by progressive muscle weakness affecting primarily or predominantly the pelvic and/or shoulder girdle muscles and 2) dystrophic or myopathic features at muscle biopsy (if performed). Pathological analyses of muscle tissues were performed at the Institute of Pathology, University Hospital Brno, Brno and the Department of Pathology and Molecular Medicine, University Hospital Motol, Prague. Detailed clinical information was requested retrospectively on the basis of positive results of DNA analysis. Patients diagnosed with Duchenne muscular dystrophy, spinal muscular atrophy type III, or facioscapulohumeral muscular dystrophy were excluded using DNA analysis, and those with late-onset Pompe disease using the enzyme assay. DNA analysis reported in this study was performed with the approval of the Ethical Committee of the University Hospital Brno, and all patients or their parents gave their informed consent for participation in the study.

\section{Analysis of muscle tissue}

Muscle tissues were routinely examined by conventional histopathological methods. Muscle protein analyses were performed using immunohistochemistry and immunoblotting as described in our previous studies [25-27].

\section{DNA analysis}

Genomic DNA was extracted from peripheral blood leukocytes by the standard salting-out method and amplified. Sequences of primers for amplification of all exons and adjacent intron sequences are available on request, as well as the conditions of particular PCRs. PCR products were 
sequenced directly using the BigDye Terminator Cycle Sequencing Kit (Applied Biosystems) and analysed on the ABI PRISM 310 or ABI 3130xl Genetic Analyzer (Applied Biosystems). The resulting sequences were compared with the reference sequences of CAPN3 (NCBI NG_ 008660.1), FKRP (NCBI NG_008898.1), SGCA (NCBI NG_008889.1), ANO5 (NCBI NG_015844.1), DYSF (NCBI NG_008694.1), and SGCB (NCBI NG_008891.1). To find out whether the sequence variations detected had been described previously, we used the literature and the Leiden Muscular Dystrophy Pages (LMDP, http://www. dmd.nl/nmdb/home.php?action=switch_db). All novel missense mutations were screened in a control panel consisting of DNA from 150 healthy Czech individuals. The in silico approaches PolyPhen (http://genetics.bwh.harvard. edu/pph2/index.shtml), SIFT (http://sift.jcvi.org/www/ SIFT_BLink_submit.html), and PON-P (http://structure. bmc.lu.se/PON-P2/), were used for predicting effects of novel missense mutations on the function and the structure of proteins. For prediction of effects of mutations on splicing of pre-mRNA, the in silico tools NetGene2 (http:// www.cbs.dtu.dk/services/NetGene2/) and SpliceView (http:// bioinfo4.itb.cnr.it/ webgene/wwwspliceview_ex.html) were used. The nomenclature of mutations was implemented according to the current HGVS recommendations (http:// www.hgvs.org/mutnomen/). In patients with one mutation in the CAPN3 gene, detection of deletions/duplications was performed using multiplex ligation-dependent probe amplification (MLPA). We used the SALSA MLPA P176 CAPN3 probemix kit (MRC Holland) according to the manufacturer's guidelines. Some CAPN3 mutations were also described at the mRNA level in our previous studies [25-27].

We started DNA analysis of LGMD2 patients in 2002 when sequencing analysis of the CAPN3 gene was introduced, and results for other genes were integrated subsequently. Patients were analysed step by step for mutations in the CAPN3, FKRP, SGCA, and ANO5 genes. In CAPN3 and $S G C A$, all exons and adjacent intron regions were sequenced. In FKRP and ANO5, we analysed only exons with the occurrence of the most common mutations $\mathrm{p}$. Leu276Ile and c.191dupA, respectively. In case of patients heterozygous for these mutations, analysis of all exons of a relevant gene was performed. The mentioned genes were selected on the basis of published results related to a higher incidence of associated types of LGMD2 in European populations [28-30]. The CAPN3 gene was analysed in 218 Czech LGMD2 probands; the most common mutation p.Leu276Ile in the FKRP gene in 151 probands (negative for CAPN3 mutations); the SGCA gene in 142 probands (negative for CAPN3 and FKRP mutations); and the most common mutation c.191dupA in the ANO5 gene in 136 probands (negative for CAPN3, FKRP, and SGCA mutations). Two patients carried the mutation p.Leu276Ile on only one FKRP allele and similarly 3 patients carried the mutation c.191dupA on only one ANO5 allele. As mentioned above, analysis of all exons of the corresponding gene was performed in these cases.

\section{Sequence capture and targeted resequencing (SeqCap-RT)}

For identification of mutations associated with neuromuscular disorders, we introduced the solution-based capture method SeqCap EZ Choice Library (Roche NimbleGene) and targeted resequencing on the GS Junior System (Roche) in 2013. A custom capture array was designed to capture exons and adjacent intron sequences of 42 genes (1020 exons, $280 \mathrm{~kb}$ ) known to be associated with muscular dystrophies (Group 1), congenital muscular dystrophies (Group 2), congenital myopathies (Group 3), distal myopathies (Group 4), and other myopathies (Group 5), according to www.musclegenetable.fr/. The list of selected diseases and genes includes Duchenne muscular dystrophy $(D M D)$, Emery-Dreifuss muscular dystrophy (EMD, FHL1, LMNA), limb-girdle muscular dystrophy (MYOT, LMNA, CAV3, CAPN3, DYSF, SGCG, SGCA, SGCB, SGCD, TCAP, TRIM32, FKRP, TTN, POMT1, ANO5, FKTN, POMT2, POMGNT1), and additionally genes associated with congenital muscular dystrophies (LAMA2, LARGE, SEPN1, COL6A1, COL6A2, COL6A3, ITGA7, DNM2), congenital myopathies, distal myopathies, and other myopathies (NEB, TPM3, ACTA1, TPM2, TNNT1, CFL2, RYR, MTM1, BIN, CRYAB, $D E S$, $L A M P 2, P A B P N 1)$. Probes for the target regions were designed according to the "NimbleGen Sequence Capture Custom Designs" protocol. Sequence capture was performed according to the manufacturer's instructions (NimbleGen SeqCap EZ Choice Library LR User's Guide) with modifications of DNA fragmentation and hybridisation. We replaced nebulization by shearing using the S220 Focused Ultrasonicator (Covaris) (3 $\mu \mathrm{g}$ DNA, peak incident power $140 \mathrm{~W}$, duty factor $10 \%$, 200 cycles per burst, and treatment time 80 s) and replaced hybridization for three days by hybridization according to the NimbleGen technical note "Double Capture High Efficiency Sequence Capture of Small Targets for use in SeqCap EZ Library, Applications on 454 Sequencing Systems". Emulsion PCR and sequencing on the GS Junior System (Roche) were performed according to the "emPCR Amplification Method Manual - Lib-L" and the "Sequencing Method Manual". Sequencing data were evaluated using the software Sequence Pilot (JSI Medical Systems).

In the period of this study SeqCap-TR was performed in 20 probands of whom 4 had the phenotype of LGMD2 and were negative for CAPN3, FKRP, SGCA, and ANO5 mutations. Here we present only results for patients in which mutations in genes associated with LGMD2 were identified, and the global results and results related to other genes are the subject of another study to be published. 
Table 1 Mutations identified in Czech LGMD2A probands

\begin{tabular}{|c|c|c|}
\hline No. & Mutations (cDNA level) & Mutations (protein level) \\
\hline $1-23$ & c.550delA/c.550delA & p.(Thr184Argfs*36)/p.(Thr184Argfs*36) \\
\hline 24,25 & c.550delA/c.245C > T & p.(Thr184Argfs*36)/p.(Pro82Leu) \\
\hline 26 & c.550delA/c.328C > T & p.(Thr184Argfs*36)/p. $\left(\operatorname{Arg} 110^{*}\right)$ \\
\hline 27 & c.550delA/c.509A > G & p.(Thr184Argfs*36)/p.(Tyr170Cys) \\
\hline 28 & c.550delA/c.598_612del & p.Thr184Argfs*36/p.Phe200_Leu204del \\
\hline 29 & c.550delA/c.1043delG & p.(Thr184Argfs*36)/p.(Gly348Valfs*4) \\
\hline 30 & c.550delA/c.1069C > T & p.(Thr184Argfs*36)/p.(Arg357Trp) \\
\hline 31 & c.550delA/c.1451T > C & p.(Thr184Argfs*36)/p.(Leu484Pro) \\
\hline 32 & c.550delA/c.1465C > T & p.(Thr184Argfs*36)/p.(Arg489Trp) \\
\hline 33,34 & c.550delA/c.1468C > T & p.Thr184Argfs*36/p.(Arg490Trp) \\
\hline 35 & c.550delA/c.1470delG & p.(Thr184Argfs*36)/p.(Arg490Argfs*6) \\
\hline 36,37 & c.550delA/c.1722delC & p.Thr184Argfs*36/p.Ser575Leufs*20 \\
\hline 38 & c.550delA/c.1823G > A & p.(Thr184Argfs*36)/p.(Arg608Lys) \\
\hline 39 & c.550delA/c.1981delA & p.Thr184Argfs*36/p.lle661* \\
\hline 40 & c.550delA/c.2245A > C & p.(Thr184Argfs*36)/p.(Asn749His) \\
\hline 41 & c. $1 \mathrm{~A}>\mathrm{G} / \mathrm{c} .865 \mathrm{C}>\mathrm{T}$ & p.(Met1Val)/p.(Arg289Trp) \\
\hline 42 & c.133G $>A / c .133 G>A$ & p.Ala45Thr/p.Ala45Thr \\
\hline 43 & c. $146 \mathrm{G}>\mathrm{A} / \mathrm{c} .1069 \mathrm{C}>\mathrm{T}$ & p.(Arg49His)/p.(Arg357Trp) \\
\hline 44 & c. $224 \mathrm{~A}>\mathrm{G} / \mathrm{c} .224 \mathrm{~A}>\mathrm{G}$ & p.Tyr75Cys/p.Tyr75Cys \\
\hline 45 & $c .245 C>T / C .245 C>T$ & p.Pro82Leu/p.Pro82Leu \\
\hline 46 & c. $245 C>T / \mathbf{c} .1800+1 G>A$ & p.(Pro82Leu)/splicing \\
\hline 47 & c. $245 C>T / \mathbf{c} .1855 C>T$ & p.(Pro82Leu)/p.(Gln619*) \\
\hline 48 & c.245C > T/c.2314_2317del & p.Pro82Leu/p.Asp772Asnfs*3 \\
\hline 49 & c.509A $>\mathrm{G} / \mathrm{c} .509 \mathrm{~A}>\mathrm{G}$ & p.(Tyr170Cys)/p.(Tyr170Cys) \\
\hline 50 & c.598_612del/c.598_612del & p.(Phe200_Leu204del)/p.(Phe200_Leu204del) \\
\hline 51 & c.598_612del/c.640G > A & p.(Phe200_Leu204del)/p.(Gly214Ser) \\
\hline 52 & c.598_612del/c.2245A >C & p.Phe200_Leu204del/p.Asn749His \\
\hline 53 & c.1043delG/c.1094G > A & p.(Gly348Valfs*4)/p.(Trp365*) \\
\hline 54 & c.1043delG/c.1343G > A & p.(Gly348Valfs*4)/p.(Arg448His) \\
\hline 55 & c. $1194-9 A>$ G/c.1800 + 1G > A & splicing/splicing \\
\hline 56 & c.1194-9A > G/c.2393C > A & splicing/p.(Ala798Glu) \\
\hline 57 & C. $1250 \mathrm{C}>\mathrm{T} / \mathrm{C} .1250 \mathrm{C}>\mathrm{T}$ & p.(Thr417Met)/p.(Thr417Met) \\
\hline 58 & c. $1322 \mathrm{G}>\mathrm{A} / \mathrm{c} .1322 \mathrm{G}>\mathrm{A}$ & p.Gly441Asn/p.Gly441Asn \\
\hline 59 & c.1322delG/c.2114A > G & p.(Gly441Valfs*22)/p.(Asp705Gly) \\
\hline 60 & c.1343G > A/c.2093G > A & p.(Arg448His)/p.(Arg698His) \\
\hline 61 & c.1468C > T/c.2314_2317del & p.(Arg490Trp)/p.(Asp772Asnfs*3) \\
\hline 62 & c.1788_1793del/c.2242C > T & p.Lys597_Lys598del/p.Arg748* \\
\hline $63-66$ & c.598_612del/c.1746-20C > G & p.(Phe200_Leu204del)/splicing \\
\hline 67 & c.614T > C/c.1746-20C > G & p.(Leu205Pro)/splicing \\
\hline 68,69 & c.550delA/- & p.(Thr184Argfs*36)/- \\
\hline 70,71 & c.598_612del/- & p.(Phe200_Leu204del)/- \\
\hline
\end{tabular}

Mutations in bold letters were detected only in Czech LGMD2A patients. 


\section{Results and discussion}

Considering the wide clinical and genetic variability of LGMD, determination of particular types is a comprehensive process. Muscle biopsies still represent an important and economical step in diagnosis, but protein changes documented by immunohistochemistry can be secondary or not pronounced and therefore a definitive diagnosis requires genetic analysis. Mutations of the CAPN3 gene are the most common cause of LGMD2, and in the set of 218 Czech probands with a suspicion of LGMD2 two mutations in this gene were identified in 67 patients. In 4 patients only one CAPN3 mutation was determined, and sequence analysis was completed by MLPA but no gene deletions/duplications were found (Table 1). In total we identified 37 different mutations of which 12 have been described only in Czech LGMD2A patients. The most frequent mutation among our LGMD2A probands is c.550delA which was detected in 65 mutant alleles from the total number of 138 (47.1\%). The patients' clinical and pathological findings (when available) are presented in (Additional file 1: Table S1).

Probands negative for CAPN3 mutations (151) were analysed for the most common mutation in the FKRP gene, p.Leu276Ile. The homozygous occurrence of this mutation was identified in 7 patients. In two patients heterozygous for p.(Leu276Ile), we were able to identify a second mutation: patient 79 carries the mutation p.(Pro316Arg) described in [12] and patient 80 has the new mutation p.(Trp359Ser) (Table 2).

In 142 probands without mutations in the CAPN3 or FKRP genes, we performed analysis of the SGCA gene. Mutations were detected in 6 patients (Table 2). The most common mutation among our LGMD2D patients is p.(Arg77Cys), which was present in 4 mutant alleles.
We also identified one new SGCA mutation, c.303dupA (patient 85).

Probands negative for CAPN3, FKRP, and SGCA mutations (136) were screened for the most common mutation in the ANO5 gene, c.191dupA. This mutation was found heterozygously in 3 patients, and subsequent sequencing analysis of all exons and adjacent intron regions detected the mutation p.(Arg758Lys) in two of them (Table 2). This mutation was described in combination with c.191dupA in other studies [24], [31] and the associated phenotypes corresponded to distal nondysferlin Miyoshi myopathy, unlike our patient 88 whose phenotype matches rather LGMD2L (a detailed description of the phenotype of patient 89 was not available). Analysis for this mutation was subsequently performed in all LGMD2 patients with unconfirmed diagnosis at the DNA level, but it was not detected. In patient 87 carrying c.191dupA on one allele, we did not identify a second mutation but only the polymorphism p.(Leu322Phe) described in LMDP. The patient's clinical and pathological findings are presented in (Additional file 2: Table S2).

The aim of this study was to evaluate the relative proportion of the most frequent types of LGMD2 identified in other European countries in Czech probands with a suspicion of LGMD2. The results show that the frequency of the forms of LGMD2 which were analysed is $32.6 \%$ for LGMD2A (71 probands), $4.1 \%$ for LGMD2I (9 probands), 2.8\% for LGMD2D (6 probands), and $1.4 \%$ for LGMD2L (3 probands). These results indicate that there is good agreement between the frequency of particular forms of LGMD2 in the Czech Republic and in Italy (respectively LGMD2A 31.1\%, LGMD2I 7.4\%, LGMD2D 8.4\%, LGMD2L 2.1\% [28] and LGMD2A 28.4\%, LGMD2I 6.4\%, LGMD2D 8.3\%

Table 2 Mutations identified in Czech LGMD2I, 2D, 2 L, 2B, and 2E probands

\begin{tabular}{|c|c|c|c|}
\hline No. & Gene & Mutation (cDNA level) & Mutation (protein level) \\
\hline $72-78$ & FKRP & $c .826 C>A / c .826 C>A$ & p.(Leu276lle)/p.(Leu276\|le) \\
\hline 79 & FKRP & c. $.826 C>A / c .947 C>G$ & p.(Leu276lle)/p.(Pro316Arg) \\
\hline 80 & FKRP & C. $826 C>A / \mathbf{c} .1076 G>C$ & p.(Leu276lle)/p.(Trp359Ser) \\
\hline 81 & $S G C A$ & c.229C > T/c.229C > T & p.(Arg77Cys)/p.(Arg77Cys) \\
\hline 82,83 & SGCA & c. $157+1 G>A / c .850 C>T$ & splicing/p.(Arg284Cys) \\
\hline 84 & SGCA & c. $229 \mathrm{C}>\mathrm{T} / \mathrm{c} .739 \mathrm{G}>\mathrm{A}$ & p.(Arg77Cys)/p.(Val247Met) \\
\hline 85 & $S G C A$ & c.290A > G/c.303dupA & p.(Asp97Gly)/p.(Gln101Glnfs*4) \\
\hline 86 & $S G C A$ & c.229C > T/C.308 T>C & p.(Arg77Cys)/p.(lle103Thr) \\
\hline 87 & ANO5 & c.191dupA/c.966A > T & p.(Asn64Lysfs*15)/p.(Leu322Phe) \\
\hline 88,89 & ANO5 & c.191dupA/c.2272C > T & p.(Asn64Lysfs*15)/p.(Arg758Cys) \\
\hline 90 & DYSF & c. $3832 C>T /$ c.5509G $>$ T & p.(Gln1278*)/p.(Asp1837Tyr) \\
\hline 91 & DYSF & c.509C > A/c.5907G >C/c.610C > T/C.1120G >C/ & p.(Ala170Glu)/p.(Trp1969Cys)/p.(Arg204*)/p.(Val374Leu)/ \\
\hline 92 & $S G C B$ & c.341C > T/c.341C > T & p.(Ser114Phe)/p.(Ser114Phe) \\
\hline
\end{tabular}

Mutations in bold letters were detected only in Czech LGMD2 patients. The variant c.966A $>T$ in italics is probably a nucleotide polymorphism (LMDP, dbSNP-rs7481951). 
[2]), in contrast to studies from Denmark where the frequency of LGMD2A is significantly lower (12.1\%) and that of LGMD2I significantly higher (38.4\%) [29] (Table 3).

Histopathological and immunohistochemical analysis of muscle tissue performed in 42 of the 71 patients with identified mutation(s) in the CAPN3 gene showed that 34 patients had a dystrophic and 8 had a myopathic pattern of muscle tissue. Immunoblotting of the CAPN3 protein was implemented in 33 patients. In patients with a mutation creating a protein termination codon (PTC) on both CAPN3 alleles, immunoblotting showed the absence of $94 \mathrm{kDa}$ CAPN3 (16 cases); in patients with a combination PTC/missense mutation we noted the absence (4 patients) or weak labelling (2 patients) of CAPN3; and in cases with a combination missense/missense mutation we detected the absence ( 2 patients), weak labelling (1 patient), or normal labelling (1 patient) of CAPN3. Other cases encompassing combinations of in-frame deletions, splicing mutations, or with a mutation on one CAPN3 allele occurred exceptionally (Additional file 1).

Analysis of muscle tissue performed in 6 patients with mutations in the FKRP gene showed a dystrophic pattern of muscle tissue. In two cases (patients 72 and 78), immunohistochemical analysis of alpha-dystroglycan was performed and both patients had a deficit of this protein. Three patients with mutations in the SGCA gene showed absence or weak labelling of alpha, beta, and gamma-sarcoglycans (patients 82, 85), but in contrast immunodetection of these proteins was normal in patient 84 (Additional file 2).

In 2013, we introduced the SeqCap-TR method for genetic diagnosis of neuromuscular disorders and this approach was applied in 20 patients, 4 of whom had the LGMD2 phenotype and were negative for CAPN3, FKRP, $S G C A$, and $A N O 5$ mutations. We identified two patients with LGMD2B (mutations in the DYSF gene), one patient with LGMD2E (mutations in the $S G C B$ gene), and one patient is without identified causal mutations as yet. Patient 90 is a compound heterozygote for two DYSF mutations (genotype p.[Gln1278*]; [Asp1837Tyr]). Compound heterozygous and homozygous occurrence of $\mathrm{p}$. (Gln1278*) was described in [36], in the case of a homozygous patient an initial phenotype corresponded to Miyoshi myopathy. The mutation c.5509G > T, p.(Asp1837Tyr) was not reported so far, but c.5509G > A, p.(Asp1837Asn) was described in several studies. In [37] a patient carried the genotype p.[Asp1837Asn]; [Trp1968*] and the phenotype of LGMD2B, and in [38] and [39] patients with the genotype p.[Asp1837Asn]; [Tyr522*] had Miyoshi myopathy. In cases of homozygous occurrence of this mutation, phenotypes of Miyoshi myopathy [40-42] and also of LGMD2B [42] were observed. The phenotype of our patient 90 corresponded rather with LGMD2B. Patient 91 carries 4 mutations in the DYSF gene, p. (Ala170Glu), p.(Arg204*), p.(Val374Leu), and the novel mutation p.(Trp1969Cys). The mutation p.(Ala170Glu) is described in the LMDP as unknown pathogenic, probably

Table 3 Frequency of LGMD2A, 2I, 2D, 2 L in European countries

\begin{tabular}{|c|c|c|c|c|c|c|}
\hline $\begin{array}{l}\text { Litera- } \\
\text { ture }\end{array}$ & Population & $\begin{array}{l}\text { Number of patients analysed } \\
\text { in the study }\end{array}$ & $\begin{array}{l}\text { Number and percentage } \\
\text { of patients with LGMD2A }\end{array}$ & $\begin{array}{l}\text { Number and percentage } \\
\text { of patients with LGMD2I }\end{array}$ & $\begin{array}{l}\text { Number and } \\
\text { percentage of } \\
\text { patients with } \\
\text { LGMD2D }\end{array}$ & $\begin{array}{l}\text { Number and } \\
\text { percentage of } \\
\text { patients with } \\
\text { LGMD2L }\end{array}$ \\
\hline $\begin{array}{l}\text { This } \\
\text { study }\end{array}$ & Czech & 218 LGMD2 probands & $\begin{array}{l}71 \text { ( } 67 \text { had two mutations, } \\
4 \text { one); } \mathbf{3 2 . 6 \%}\end{array}$ & $9 ; 4.1 \%$ & $6 ; 2.8 \%$ & $3 ; 1.4 \%$ \\
\hline$[28]$ & Italy & 190 LGMD probands & $59 ; \mathbf{3 1 . 1 \%}$ & $14 ; 7.4 \%$ & $16 ; \mathbf{8 . 4 \%}$ & $4 ; 2.1 \%$ \\
\hline$[2]$ & Italy & 155 LGMD probands & $\begin{array}{l}44 \text { (30 had two mutations, } \\
14 \text { one); } \mathbf{2 8 . 4 \%}\end{array}$ & $10 ; 6.4 \%$ & $13 ; \mathbf{8 . 4 \%}$ & $\mathrm{NI}$ \\
\hline$[32]$ & Italy & $\begin{array}{l}550 \text { patients with LGMD, myopathy, } \\
\text { or asymptomatic hyperCKemia }\end{array}$ & $102 ; 18.5 \%$ & $16 ; \mathbf{2 . 8} \%$ & $37 ; 6.7 \%$ & $\mathrm{NI}$ \\
\hline$[33]$ & Italy & $\begin{array}{l}519 \text { patients with LGMD, myopathy, } \\
\text { or asymptomatic hyperCKemia }\end{array}$ & $\begin{array}{l}94 \text { (76 had two mutations, } \\
18 \text { one); } \mathbf{1 8 . 1 \%}\end{array}$ & $\mathrm{NI}$ & $\mathrm{NI}$ & $\mathrm{NI}$ \\
\hline$[10]$ & Italy & 530 patients with muscular dytrophy & $\begin{array}{l}141 \text { (104 had two mutations } \\
\text { and } 37 \text { one); } \mathbf{2 6 . 6 \%}\end{array}$ & $\mathrm{NI}$ & $\mathrm{NI}$ & $\mathrm{NI}$ \\
\hline$[34]$ & Italy & $\begin{array}{l}214 \text { probands with muscular } \\
\text { dystrophy or myopathy }\end{array}$ & $\mathrm{NI}$ & $\begin{array}{l}13 \text { (9 had two mutations, } \\
4 \text { one); } \mathbf{6 . 1 \%}\end{array}$ & $\mathrm{NI}$ & $\mathrm{NI}$ \\
\hline$[35]$ & Germany & $\begin{array}{l}98 \text { probands with LGMD2 and } 102 \\
\text { probands with asymptomatic or } \\
\text { minimally symptomatic hyperCKemia }\end{array}$ & $\mathrm{NI}$ & $7 ; 3.5 \%$ & $\mathrm{NI}$ & $\mathrm{NI}$ \\
\hline$[29]$ & Denmark & 99 LGMD2 patients & $12 ; \mathbf{1 2 . 1 \%}$ & $38 ; 38.4 \%$ & $\mathrm{NI}$ & $\mathrm{NI}$ \\
\hline$[4]$ & Dutch & 67 LGMD probands & $14 ; \mathbf{2 0 . 9 \%}$ & $5 ; 7.5 \%$ & $\mathrm{NI}$ & $\mathrm{NI}$ \\
\hline [30] & Dutch & 68 LGMD probands & $\mathrm{NI}$ & $\mathrm{NI}$ & $\mathrm{NI}$ & $11 ; \mathbf{1 6 . 2 \%}$ \\
\hline
\end{tabular}

NI: no information. 
pathogenic, or pathogenic and p.(Val374Leu) as probably not pathogenic or pathogenic. The evaluation of these missense mutations using in silico tools is described in (Additional file 3: Table S3) together with the evaluation of selected missense mutations identified in the genes analysed. DNA analysis was performed in patient's parents; her father carries p.(Arg204*) and p.(Val374Leu), and her mother carries p.(Ala170Glu) and p.(Trp1969Cys). On the basis of the in silico analyses and inheritance in the patient's family, we suppose that p.(Arg204*) and p.(Trp1969Cys) are causal mutations. Patient 92 is homozygous for the SGCB mutation p.(Ser114Phe) described in the LMDP in association with LGMD2E. The patients' clinical and pathological findings are shown in (Additional file 2: Table S2). None of the novel missense mutations were detected in 150 control DNA samples.

\section{Conclusions}

We characterised a cohort of Czech LGMD2 patients on the basis of analysis of mutations in genes associated with the most common forms of LGMD2 in the European population and compared these results with published studies. This study expands our previous results for the Czech LGMD2A population [25-27], as well as the spectrum of mutations in other types of LGMD2, and further provides information concerning clinical and genetic correlations. At the present time, molecular genetic diagnosis of Czech LGMD2 patients follows the following scheme: sequencing of all exons and adjacent intron regions of the CAPN3 gene, detection of the most common mutation p.Leu276Ile in the FKRP gene, and sequence capture and targeted resequencing of genes associated with neuromuscular disorders.

\section{Additional files}

Additional file 1: Table S1. Mutations and pathological-clinical findings identified in Czech LGMD2A probands.

Additional file 2: Table S2. Mutations and pathological-clinical findings identified in Czech LGMD2I, 2D, 2L, 2B, and 2E probands.

Additional file 3: Table S3. In silico prediction of effects of selected missense mutations.

\section{Abbreviations}

DAG complex: Dystrophin-associated glycoprotein complex; LGMD: Limb-girdle muscular dystrophy; LMDP: Leiden muscular dystrophy pages; MLPA: Multiplex ligation-dependent probe amplification; SG complex: Sarcoglycan complex; SeqCap-TR: Sequence capture and targeted resequencing.
\end{abstract}

\section{Competing interests}

The authors declare that they have no competing interests.

\section{Authors' contributions}

$\mathrm{KS}, \mathrm{DS}$, JZ carried out the molecular genetic studies. LM, PV, RM, SV, JH, HO, ND, PS performed clinical diagnostics of LGMD patients. MH, JZ, OS were involved in pathological analysis of muscle tissue. LF participated in design study and manuscript preparation. All authors read and approved the final manuscript.

\section{Acknowledgements}

This work was funded by projects of the Internal Grant Agency of the Czech Ministry of Health (NT/14574-3), the Czech Ministry of Education "CEITEC - Central European Institute of Technology" (CZ.1.05/1.1.00/02.0068) and SuPReMMe (CZ.1.07/2.3.00/20.0045), and the Czech Ministry of Health for conceptual development of research organization 65269705 (University Hospital Brno, Brno, Czech Republic) and MH - DRO, University Hospital Motol, Prague, Czech Republic 00064203

We would like to thank the physicians from Departments of Neurology and Medical Genetics in the Czech Republic (Drs. P. Doležalová, M. Forgáč, R. Gaillyová, D. Grečmalová, A. Gřegořová, M. Havlová, T Honzík, P. Ješina, Z. Kalina, K. Kalous, V. Krìvková, R. Kutějová, M. Langová, T. Mařiková, Š. Prášilová, D. Polendová, M. Soukupová, J. Staněk, M. Ševčíková, E. Šilhánová, S. Širǔčková, D. Tenora, J. Zvolská) for providing us with their patients' blood samples.

\section{Author details}

${ }^{1}$ Centre of Molecular Biology and Gene Therapy, University Hospital Brno, Černopolní 9, 61300 Brno, Czech Republic. ${ }^{2}$ Central European Institute of Technology, Masaryk University, Kamenice 5, CZ-62500 Brno, Czech Republic. ${ }^{3}$ Department of Child Neurology, University Hospital Brno, Černopolní 9, 613 00 Brno, Czech Republic. ${ }^{4}$ Department of Neurology, Second Faculty of Medicine, Charles University and University Hospital Motol, V Úvalu 84, 150 06 Prague, Czech Republic. ${ }^{5}$ Department of Neurology, University Hospital Brno, Jihlavská 20, 62500 Brno, Czech Republic. ${ }^{6}$ Department of Child Neurology, Second Faculty of Medicine, Charles University and University Hospital Motol, V Úvalu 84, 15006 Prague, Czech Republic. ${ }^{7}$ First Department of Pathological Anatomy, Faculty of Medicine, Masaryk University and St. Anne's University Hospital, Pekařská 53, 65691 Brno, Czech Republic.

${ }^{8}$ Department of Pathology and Molecular Medicine, Second Faculty of Medicine, Charles University and University Hospital Motol, V Úvala 84, 150 06 Prague, Czech Republic. Institute of Pathology, University Hospital Brno, Jihlavská 20, 62500 Brno, Czech Republic. ${ }^{10}$ Departmemt of Medical Genetics, University Hospital Ostrava, 17. Listopadu 1790, 70852 Ostrava, Czech Republic. "'Department of Medical Genetics, University Hospital Hradec Králové, Sokolská 581, 50005 Hradec Králové, Ostrava, Czech Republic.

Received: 12 May 2014 Accepted: 21 July 2014

Published: 19 August 2014

\section{References}

1. Kang PB, Feener CA, Estrella E, Thorne M, White AJ, Darras BT, Amato AA, Kunkel LM: LGMD2I in a North American population. BMC Musculoskelet Disord 2007, 8:115.

2. Guglieri M, Magri F, D'Angelo MG, Prelle A, Morandi L, Rodolico C, Cagliani R, Mora M, Fortunato F, Bordoni A, Del Bo R, Ghezzi S, Pagliarani S, Lucchiari S, Salani S, Zecca C, Lamperti C, Ronchi D, Aguennouz M, Ciscato P, Di Blasi C, Ruggieri A, Moroni I, Turconi A, Toscano A, Moggio M, Bresolin N, Comi GP: Clinical, molecular, and protein correlations in a large sample of genetically diagnosed Italian limb girdle muscular dystrophy patients. Hum Mutat 2008, 29(2):258-266.

3. Lo HP, Cooper ST, Evesson FJ, Seto JT, Chiotis M, Tay V, Compton AG, Cairns AG, Corbett A, MacArthur DG, Yang N, Reardon K, North KN: Limb-girdle muscular dystrophy: diagnostic evaluation, frequency and clues to pathogenesis. Neuromuscul Disord 2008, 18(1):34-44.

4. van der Kooi AJ, Frankhuizen WS, Barth PG, Howeler CJ, Padberg GW, Spaans F, Wintzen AR, Wokke JH, van Ommen GJ, de Visser M, Bakker E, Ginjaar HB: Limb-girdle muscular dystrophy in the Netherlands: gene defect identified in half the families. Neurology 2007, 68(24):2125-2128.

5. Zatz M, Vainzof M, Passos-Bueno MR: Limb-girdle muscular dystrophy: one gene with different phenotypes, one phenotype with different genes. Curr Opin Neurol 2000, 13(5):511-517.

6. Richard I, Broux O, Allamand V, Fougerousse F, Chiannilkulchai N, Bourg N, Brenguier L, Devaud C, Pasturaud P, Roudaut C, Hillaire D, Passos-Bueno MR, Zatz M, Tischfield JA, Fardeau M, Jackson CE, Cohen D, Beckmann JS: Mutations in the proteolytic enzyme calpain 3 cause limb-girdle muscular dystrophy type 2A. Cell 1995, 81(1):27-40.

7. Sorimachi H, Kinbara K, Kimura S, Takahashi M, Ishiura S, Sasagawa N, Sorimachi N, Shimada H, Tagawa K, Maruyama K, Suzuki K: Muscle-specific calpain, p94, responsible for limb girdle muscular dystrophy type $2 \mathrm{~A}$, 
associates with connectin through IS2, a p94-specific sequence. J Biol Chem 1995, 270(52):31158-31162.

8. Keira Y, Noguchi S, Minami N, Hayashi YK, Nishino I: Localization of calpain 3 in human skeletal muscle and its alteration in limb-girdle muscular dystrophy 2A muscle. J Biochem 2003, 133(5):659-664.

9. Fanin M, Fulizio L, Nascimbeni AC, Spinazzi M, Piluso G, Ventriglia VM, Ruzza G, Siciliano G, Trevisan CP, Politano L, Nigro V, Angelini C: Molecular diagnosis in LGMD2A: mutation analysis or protein testing? Hum Mutat 2004, 24(1):52-62.

10. Piluso G, Politano L, Aurino S, Fanin M, Ricci E, Ventriglia VM, Belsito A, Totaro A, Saccone V, Topaloglu H, Nascimbeni AC, Fulizio L, Broccolini A, Canki-Klain N, Comi LI, Nigro G, Angelini C, Nigro V: Extensive scanning of the calpain-3 gene broadens the spectrum of LGMD2A phenotypes. J Med Genet 2005, 42(9):686-693.

11. Saenz A, Leturcq F, Cobo AM, Poza JJ, Ferrer X, Otaegui D, Camano P, Urtasun M, Vilchez J, Gutierrez-Rivas E, Emparanza J, Merlini L, Paisán C, Goicoechea M, Blázquez L, Eymard B, Lochmuller H, Walter M, Bonnemann C, Figarella-Branger D, Kaplan JC, Urtizberea JA, Martí-Massó JF, López De Munain A: LGMD2A: genotype-phenotype correlations based on a large mutational survey on the calpain 3 gene. Brain 2005, 128(Pt 4):732-742.

12. Brockington M, Blake DJ, Prandini P, Brown SC, Torelli S, Benson MA, Ponting CP, Estournet B, Romero NB, Mercuri E, Voit T, Sewry CA, Guicheney $P$, Muntoni $F$ : Mutations in the fukutin-related protein gene (FKRP) cause a form of congenital muscular dystrophy with secondary laminin alpha2 deficiency and abnormal glycosylation of alpha-dystroglycan. Am J Hum Genet 2001, 69(6):1198-1209.

13. Mercuri E, Brockington M, Straub V, Quijano-Roy S, Yuva Y, Herrmann R, Brown SC, Torelli S, Dubowitz V, Blake DJ, Romero NB, Estournet B, Sewry CA, Guicheney P, Voit T, Muntoni F: Phenotypic spectrum associated with mutations in the fukutin-related protein gene. Ann Neurol 2003, 53(4):537-542.

14. Walter MC, Petersen JA, Stucka R, Fischer D, Schroder R, Vorgerd M, Schroers A, Schreiber H, Hanemann CO, Knirsch U, Rosenbohm A, Huebner A, Barisic N, Horvath R, Komoly S, Reilich P, Müller-Felber W, Pongratz D, Müller JS, Auerswald EA, Lochmüller H: FKRP $(826 C>A)$ frequently causes limb-girdle muscular dystrophy in German patients. J Med Genet 2004, 41(4):e50.

15. Frosk $P$, Greenberg CR, Tennese AA, Lamont R, Nylen E, Hirst C, Frappier D, Roslin NM, Zaik M, Bushby K, Straub V, Zatz M, de Paula F, Morgan K, Fujiwara TM, Wrogemann K: The most common mutation in FKRP causing limb girdle muscular dystrophy type 2I (LGMD2I) may have occurred only once and is present in Hutterites and other populations. Hum Mutat 2005, 25(1):38-44.

16. Angelini C, Fanin M, Freda MP, Duggan DJ, Siciliano G, Hoffman EP: The clinical spectrum of sarcoglycanopathies. Neurology 1999, 52(1):176-179.

17. Straub V, Bushby K: The childhood limb-girdle muscular dystrophies. Semin Pediatr Neurol 2006, 13(2):104-114.

18. Jarry J, Rioux MF, Bolduc V, Robitaille Y, Khoury V, Thiffault I, Tetreault M, Loisel L, Bouchard JP, Brais B: A novel autosomal recessive limb-girdle muscular dystrophy with quadriceps atrophy maps to $11 \mathrm{p} 13-\mathrm{p} 12$. Brain 2007, 130(Pt 2):368-380.

19. Bolduc V, Marlow G, Boycott KM, Saleki K, Inoue H, Kroon J, Itakura M, Robitaille Y, Parent L, Baas F, Mizuta K, Kamata N, Richard I, Linssen WH, Mahjneh I, de Visser M, Bashir R, Brais B: Recessive mutations in the putative calcium-activated chloride channel Anoctamin 5 cause proximal LGMD2L and distal MMD3 muscular dystrophies. Am J Hum Genet 2010, 86(2):213-221.

20. Tsutsumi S, Kamata N, Vokes TJ, Maruoka Y, Nakakuki K, Enomoto S, Omura K, Amagasa T, Nagayama M, Saito-Ohara F, et al: The novel gene encoding a putative transmembrane protein is mutated in gnathodiaphyseal dysplasia (GDD). Am J Hum Genet 2004, 74(6):1255-1261.

21. Schroeder BC, Cheng T, Jan YN, Jan LY: Expression cloning of TMEM16A as a calcium-activated chloride channel subunit. Cell 2008, 134(6):1019-1029.

22. Yang YD, Cho H, Koo JY, Tak MH, Cho Y, Shim WS, Park SP, Lee J, Lee B, Kim BM, Raouf R, Shin YK, Oh U: TMEM16A confers receptor activated calcium-dependent chloride conductance. Nature 2008, 455(7217):1210-1215.

23. Stephan AB, Shum EY, Hirsh S, Cygnar KD, Reisert J, Zhao H: ANO2 is the cilial calcium-activated chloride channel that may mediate olfactory amplification. Proc Natl Acad Sci U S A 2009, 106(28):11776-11781.
24. Hicks D, Sarkozy A, Muelas N, Koehler K, Huebner A, Hudson G, Chinnery PF, Barresi R, Eagle M, Polvikoski T, Bailey G, Miller J, Radunovic A, Hughes PJ, Roberts R, Krause S, Walter MC, Laval SH, Straub V, Lochmüller H, Bushby K: A founder mutation in Anoctamin 5 is a major cause of limb-girdle muscular dystrophy. Brain 2011, 134(Pt 1):171-182.

25. Chrobakova T, Hermanova M, Kroupova I, Vondracek P, Marikova T, Mazanec R, Zamecnik J, Stanek J, Havlova M, Fajkusova L: Mutations in Czech LGMD2A patients revealed by analysis of calpain 3 mRNA and their phenotypic outcome. Neuromuscul Disord 2004, 14(10):659-665.

26. Hermanova M, Zapletalova E, Sedlackova J, Chrobakova T, Letocha O, Kroupova I, Zamecnik J, Vondracek P, Mazanec R, Marikova T, Vohánka S, Fajkusová L: Analysis of histopathologic and molecular pathologic findings in Czech LGMD2A patients. Muscle Nerve 2006, 33(3):424-432.

27. Stehlikova K, Zapletalova E, Sedlackova J, Hermanova M, Vondracek P, Marikova T, Mazanec R, Zamecnik J, Vohanka S, Fajkus J, Fajkusová L: Quantitative analysis of CAPN3 transcripts in LGMD2A patients: involvement of nonsense-mediated mRNA decay. Neuromuscul Disord 2007, 17(2):143-147.

28. Magri F, Del Bo R, D'Angelo MG, Sciacco M, Gandossini S, Govoni A, Napoli L, Ciscato P, Fortunato F, Brighina E, Bonato S, Bordoni A, Lucchini V, Corti S, Moggio M, Bresolin N, Comi GP: Frequency and characterisation of anoctamin 5 mutations in a cohort of Italian limb-girdle muscular dystrophy patients. Neuromuscul Disord 2012, 22(11):934-943.

29. Sveen ML, Schwartz M, Vissing J: High prevalence and phenotypegenotype correlations of limb girdle muscular dystrophy type 21 in Denmark. Ann Neurol 2006, 59(5):808-815.

30. van der Kooi AJ, Ten Dam L, Frankhuizen WS, Straathof CS, van Doorn PA, de Visser M, Ginjaar IB: ANO5 mutations in the Dutch limb girdle muscular dystrophy population. Neuromuscul Disord 2013, 23(6):456-460.

31. Sarkozy A, Hicks D, Hudson J, Laval SH, Barresi R, Hilton-Jones D, Deschauer M, Harris E, Rufibach L, Hwang E, Bashir R, Walter MC, Krause S, van den Bergh P, Illa I, Pénisson-Besnier I, De Waele L, Turnbull D, Guglieri M, Schrank B, Schoser B, Seeger J, Schreiber H, Gläser D, Eagle M, Bailey G, Walters R, Longman C, Norwood F, Winer J, et al: ANO5 gene analysis in a large cohort of patients with anoctaminopathy: confirmation of male prevalence and high occurrence of the common exon 5 gene mutation. Hum Mutat 2013, 34(8):1111-1118.

32. Fanin M, Nascimbeni AC, Aurino S, Tasca E, Pegoraro E, Nigro V, Angelini C Frequency of LGMD gene mutations in Italian patients with distinct clinical phenotypes. Neurology 2009, 72(16):1432-1435.

33. Fanin $M$, Nascimbeni $A C$, Tasca $E$, Angelini $C$ : How to tackle the diagnosis of limb-girdle muscular dystrophy 2A. Eur J Hum Genet 2009, 17(5):598-603.

34. Boito CA, Melacini P, Vianello A, Prandini P, Gavassini BF, Bagattin A, Siciliano G, Angelini C, Pegoraro E: Clinical and molecular characterization of patients with limb-girdle muscular dystrophy type 21. Arch Neurol 2005, 62(12):1894-1899.

35. Hanisch F, Grimm D, Zierz S, Deschauer M: Frequency of the FKRP mutation c.826C $>\mathrm{A}$ in isolated hyperCKemia and in limb girdle muscular dystrophy type 2 in German patients. J Neurol 2010, 257(2):300-301.

36. Krahn M, Beroud C, Labelle V, Nguyen K, Bernard R, Bassez G, FigarellaBranger D, Fernandez C, Bouvenot J, Richard I, Ollagnon-Roman E, Bevilacqua JA, Salvo E, Attarian S, Chapon F, Pellissier JF, Pouget J, Hammouda El $H$, Laforêt P, Urtizberea JA, Eymard B, Leturcq F, Lévy N: Analysis of the DYSF mutational spectrum in a large cohort of patients. Hum Mutat 2009, 30(2):E345-375.

37. De Luna N, Freixas A, Gallano P, Caselles L, Rojas-Garcia R, Paradas C, Nogales G, Dominguez-Perles R, Gonzalez-Quereda L, Vilchez JJ, Márquez C, Bautista J, Guerrero A, Salazar JA, Pou A, Illa I, Gallardo E: Dysferlin expression in monocytes: a source of mRNA for mutation analysis. Neuromuscul Disord 2007, 17(1):69-76.

38. Matsuda C, Hayashi YK, Ogawa M, Aoki M, Murayama K, Nishino I, Nonaka I, Arahata K, Brown RH Jr: The sarcolemmal proteins dysferlin and caveolin3 interact in skeletal muscle. Hum Mol Genet 2001, 10(17):1761-1766.

39. Tagawa K, Ogawa M, Kawabe K, Yamanaka G, Matsumura T, Goto K, Nonaka I, Nishino I, Hayashi YK: Protein and gene analyses of dysferlinopathy in a large group of Japanese muscular dystrophy patients. J Neurol Sci 2003, 211(1-2):23-28.

40. Rosales XQ, Gastier-Foster JM, Lewis S, Vinod M, Thrush DL, Astbury C, Pyatt R, Reshmi S, Sahenk Z, Mendell JR: Novel diagnostic features of dysferlinopathies. Muscle Nerve 2010, 42(1):14-21. 
41. Cagliani R, Magri F, Toscano A, Merlini L, Fortunato F, Lamperti C, Rodolico C, Prelle A, Sironi M, Aguennouz M, Ciscato P, Uncini A, Moggio M, Bresolin $\mathrm{N}$, Comi GP: Mutation finding in patients with dysferlin deficiency and role of the dysferlin interacting proteins annexin $\mathrm{A} 1$ and $\mathrm{A} 2$ in muscular dystrophies. Hum Mutat 2005, 26(3):283.

42. Ueyama H, Kumamoto T, Nagao S, Masuda T, Horinouchi H, Fujimoto S, Tsuda T: A new dysferlin gene mutation in two Japanese families with limb-girdle muscular dystrophy $2 \mathrm{~B}$ and Miyoshi myopathy. Neuromuscul Disord 2001, 11(2):139-145.

doi:10.1186/s12883-014-0154-7

Cite this article as: Stehlíková et al:: Autosomal recessive limb-girdle muscular dystrophies in the Czech Republic. BMC Neurology 2014 14:154.

\section{Submit your next manuscript to BioMed Central and take full advantage of:}

- Convenient online submission

- Thorough peer review

- No space constraints or color figure charges

- Immediate publication on acceptance

- Inclusion in PubMed, CAS, Scopus and Google Scholar

- Research which is freely available for redistribution 